\title{
PENTINGNYA PERAN KELUARGA DALAM PENCEGAHAN PASIEN JATUH DI RUMAH SAKIT
}

\author{
Kiki Dwi Febriyanti
}

\section{$\underline{\text { Kiifeb83@gmail.com }}$}

\begin{abstract}
Abstrak: Kejadian pasien jatuh merupakan masalah serius di rumah sakit terutama pasien rawat inap karena kejadian pasien jatuh merupakan salah satu indikator keselamatan pasien khususnya anak dan indikator mutu rumah sakit. Terjadinya insiden pasien jatuh di rumah sakit dapat mengakibatkan semakin memburuknya keadaan pasien di ruang rawat inap atau bahkan kematian pada pasien. Banyak factor yang mempengaruhi tingkat kejadian pasien jatuh, terutama peran keluarga yang mendampingi pasien saat di ruang rawat inap. Oleh Karena itu, peran keluarga dalam menjaga pasien di ruang rawat inap sangat penting juga dalam mencegah resiko tinggi pasien jatuh.
\end{abstract}

Kata kunci : pasien jatuh, peran keluarga bagi pasien, keselamatan pasien

\section{LATAR BELAKANG}

Keselamatan pasien merupakan prioritas utama yang harus dilaksanakan pihak rumah sakit. Hal ini sangat erat kaitannya baik dengan citra rumah sakit maupun keamanan pasien. Tujuan dari pelaksaan keselamatan pasien di rumah sakit adalah untuk melindungi pasien dari kejadian yang tidak diharapkan. Resiko kejadian ini berasal dari proses pelayanan yang dilakukan oleh tenaga kesehatan melalui program - program yang telah ditetapkan oleh rumah sakit (Depkes RI 2008). Lingkungan fisik yang aman adalah suatu lingkungan tempat orang dapat menjalankan fungsinya tanpa mengalami cedera dan merasa aman. Jatuh merupakan suatu yang umum terjadi pada lansia, orang sakit, atau orang cedera yang sedang lemah. Untuk mencegah klien jatuh dan mengalami cedera karenanya. Insiden jatuh ini tidak hanya berdampak pada cedera, namun juga meningkatkan lama rawatan, serta biaya rawatan pasien. Dampak cedera fisik yang dimaksud mencakup luka lecet, luka robek, luka memar, bahkan kasus berat dapat mengakibatkan fraktur, perdarahan, dan cedera kepala (Miake-Lye et al, 2013). Kerugian yang didapatkan akibat kejadian pasien jatuh ini sebaiknya dapat dicegah. 
Program untuk mencegah insiden pasien jatuh merupakan program yang sangat kompleks, karena melibatkan banyak komponen, mulai dari pimpinan, hingga kerja sama para tenaga kesehatan dan non kesehatan dari berbagai latar belakang. Keluarga memiliki peran penting setelah perawat memberikan pendidikan kesehatan dalam mencegah pasien dengan tingkat resiko tinggi jatuh dari tempat tidur. Mencegah, mengurangi dan menghindari kejadian yang membahayakan atau kejadian yang tidak diharapkan bagi pasien merupakan hal yang harus ditinjau solusi mengatasinya dalam pelayanan keperawatan. Perawat adalah salah satu profesi pemberi pelayanan kesehatan yang memiliki peranan penting dalam menentukan keberhasilan untuk meningkatkan kesejahteraan kesehatan secara keseluruhan oleh karena itu terdapat banyak hal yang harus dipelajari oleh perawat salah satunya adalah, menjaga keselamatan pasien di atas tempat tidur semua strategi dan program keselamatan pasien harus menjadi prioritas dalam pelayanan keperawatan itu sendiri sebagai mana yang kita ketahui bahwa perawat ada 24 jam untuk pasien walaupun tidak setiap saat berada dalam ruangan rawat pasien.

\section{METODE}

metode yang digunakan dalam penulisan ini adalah metode kajian bebas dimana metode ini berwilayah lebih sempit dengan tingkat variasi yang rendah, namun dari penulisan ini dapat berkembang menjadi lebih luas. Metode kajian bebas ini merupakan metode yang dilakukan untuk melakukan penulisan yang dikumpulkan dari beberapa sumber seperti buku teks, buku referensi jurnal dan e-book, dan juga dibandingkan dengan jurnal yang berhubungan dengan "pentingnya peran keluarga dalam pencegahan pasien di rumah sakit". Sehingga pembaca dapat mengerti informasi yang sudah ditulis dan dapat memahami pentingnya peran keluarga dalam pencegahan pasien di rumah sakit.

\section{HASIL}

Hasil penulisan ini meliputi gambaran tentang pentingnya peran keluarga dalam pencegahan pasien jatuh di rumah sakit. Hasil yang diharapkan dari penulisan ini adalah dapat memberikan informasi mengenai pentingnya kerja sama juga antara pasien dan pihak keluarga dalam pencegahan pasien jatuh di rumah sakit dengan cara pengidentifikasian masalah yang dialami oleh pasien yang menyebabkan pasien memiliki resiko jatuh dan dapat memberi penanganan untuk pencegahan pasien jatuh. Dimana, Tujuan 
dari penulisan ini adalah untuk membantu dalam memberikan informasi tentang pelaksanaan peningkatan keselamatan pasien dengan sasaran pengurangan resiko pasien jatuh di rumah sakit dengan bantuan keluarga pasien. Sering terjadi dalam sebuah rumah sakit sekiranya 3 pasien diantara pasien yang ada mengalami cidera karena jatuh. Pasien yang dirawat di rumah sakit merupakan individu yang sedang memiliki masalah ksehatan, sehingga sangat mungkin mengalami kesulitan memenuhi kebutuhan pribadi termasuk menjaga keselamatan sendiri, oleh sebab itu pasien membutuhkan dukungan dari keluarga dan tim kesehatan yang merawat. Kurangnya pengetahuan keluarga pasien tentang resiko jatuh yang terjadi pada pasien dengan tingkat cedera yang besar, seperti pada hal kecil yang sering dilupakan oleh perawat atau keluarga dalam memasang selalu bed side rel ketika pasien telah selesai melakukan sesuatu. Berikut pembahasan yang akan disajikan tentang pentingnya peran keluarga dalam pencegahan pasien jatuh di rumah sakit.

\section{PEMBAHASAN}

Keselamatan pasien adalah prinsip dasar dalam pelayanan kesehatan. Menurut Depkes RI (2008) Keselamatan pasien (patient safety) rumah sakit adalah suatu sistem dimana rumah sakit membuat asuhan pasien lebih aman. Sistem tersebut meliputi: assessmen risiko, identifikasi dan pengelolaan hal yang berhubungan dengan risiko pasien, pelaporan dan analisis insiden, kemampuan belajar dari insiden dan tindaklanjutnya serta implementasi solusi untuk meminimalkan timbulnya risiko. Sistem tersebut diharapkan dapat mencegah terjadinya cedera yang disebabkan oleh kesalahan akibat melaksanakan suatu tindakan atau tidak melakukan tindakan yang seharusnya dilakukan atau bahkan dikarenakan penjagaan dari pihak keluarga terhadap pasien. Dalam hal kerja sama antara pasien dan keluarga ialah jika pasien dikatakan memiliki resiko tinggi mengalami kondisi yang tidak diinginkan seperti jatuh dari tempat tidur. Kondisi pasien yang memiliki resiko tinggi diantarana, pasien lansia, pasien stroke, pasien lumpuh, dan penyakit lainnya yang menyebabkan anggota tubuh penting tidak bisa berfungsi dengan baik saat di rawat dirumah sakit.

Perawat adalah satu profesi pemberi layanan kesehatan yang memiliki peranan penting dalam menentukan keberhasilan untuk meningkatkan kesejahteraan kesehatan secara keseluruhan. Oleh karena itu, terdapat banyak hal yang harus dipelajari oleh perawat salah satunya adalah menjaga keselamatan pasien diatas tempat tidur. Semua strategi dan program keselamatan pasien harus menjadi prioritas 
dalam pelayanan keperawatan. Rumah sakit juga diberikan suatu kewajiban untuk menerapkan standar keselamatan pasien sebagai pedoman di dalam melaksanakan pelayanan kesehatan kepada pasien, hal ini berdasarkan pada pasal 7 ayat (1) PERMENKES No. 1691 Tahun 2011 tentang keselamatan pasien. Uraian atas standar keselamatan pasien sebagaimana dimaksud pada pasal 7 ayat (1) tersebut, diatur di dalam pasal 7 ayat (2) PERMENKES No. 1691 Tahun 2011 tentang keselamatan pasien yang menyatakan bahwa standar keselamatan pasien di rumah meliputi:

a. Hak pasien

b. Mendidik pasien dan keluarga

c. Keselamatan pasien dalam kesinambungan pelayanan

d. Penggunaan metode peningkatan kinerja untuk melakukan evaluasi dan program peningkatan keselamatan pasien.

e. Peran kepemimpinan dalam meningkatkan keselamatan pasien

f. Mendidik staff tentang keselamatan pasien

g. Komunikasi merupakan kunci bagi staff untuk mencapai keselamatan pasien

Kejadian pasien jatuh merupakan masalah serius di rumah sakit terutama pasien rawat inap karena kejadian pasien jatuh merupakan salah satu hal yang beresiko, sebagai perawat selain membantu individu untuk menyadari kebutuhan kesehatan dirinya sendiri dan mengarahkan dalam pencapaian kesehatan fisik optimal dan psikis pasien, perawat juga berperan penting dalam mencegah terjadinya kecelakaan pasien jatuh diatas tempat tidur yang dimana dapat menyebabkan cedera, trauma, dan dapat menyebabkan kematian bagi pasien. Kebijakan perawat dalam menjaga keamanan dan keselamatan pasien yang berada di atas tempat tidur dapat dilakukan dengan cara sebagai berikut:

1. Perawat harus membangun budaya kerja yang mementingkan keselamatan dan keamanan pasien di atas tempat tidur dengan meningkatkan kewaspadaan secara terus-menrus melalui penyelidikan, pengawasan, pengontrolan terus-menerus apalagi kepada pasien yang beresiko tinggi untuk jatuh dari atas tempat tidur , seperti pasien stroke, kesadaran diri menurun dan pasien cedera berat ataupun ringan.

2. Perawat bekerja sama dengan keluarga pasien dalam upaya menjaga keselamatan dan keamanan pasien di atas tempat tidur dengan mempertahankan komunikasi verbal dan non verbal dengan upaya perawat dalam memberikan edukasi pencegahan jatuh dengan 
memperhatikan respon keluarga pasien, sehingga keluarga pasien memahami pentingnya pencegahan pasien jatuh dari atas tempat tidur.

3. Perawat memberikan pendidikan kesehatan tentang resiko pasien jatuh atau solusi-solusi untuk mencegah kejadian yang tidak diharapkan tersebut kepada pasien dan keluarga agar pasien dan keluarga ikut waspada.

4. Perawat harus selalu memasang penyangga tempat tidur pasien atau bed side rel ketika perawat membuka penyangga tempat tidur pasien untuk melakukan tindakan perawat tidak boleh lupa menguncinya kembali setelah selesai dilakukan, karena kelupaan perawat memasang kembali bed side rel setiap selesai melakukan tindakan merupakan penyebab utama pasien jatuh dari atas tempat tidurnya.

5. Perawat mengevaluasi lingkungan pasien, evaluasi fasilitas, alat sarana dan prasarana yang berpotensi menyebabkan pasien jatuh dari atas tempat tidur dengan sebaik mungkin.

6. Apabila pasien berpotensi tinggi jatuh maka perawat mengajukan pemberian tanda resiko pasien jatuh pada tempat tidur pasien dan juga pintu kamar pasien.

7. Perawat mengajukan pasien memakai alat kaki anti licin, sediakan kursi roda yang terkunci di samping tempat tidur pasien, tempatkan alat bantu seperti wolkers atau tongkat dalam jangkauan pasien, optimalisasi penggunaan kacamata dan alat bantu dengar bagi pasien apabila diperlukan, dan nilai kebutuhan pasien yang lainnya.

8. Penggunaan bel pasien sangat penting karena kamar pasien terkadang ada yang berada jauh dari nurse station sehingga apabila keluarga pasien ingin memanggil perawat akan lama dan jauh, sedangkan di ruang tidak ada yang menunggu anknya sehingga resiko pasien jatuh menjadi lebih tinggi maka diperlukannya bel pasien untuk kewaspadaan.

Beberapa kejadian pasien jatuh juga disebabkan karena masih kurangnya sosialisasi yang dilakukan pada perawat mengenai resiko pasien jatuh, kemudian tidak tersedianya standar operasional mengenai resiko pasien jatuh di masingmasing unit rawat inap sehingga menyebabkan kurangnya pengetahuan perawat mengenai resiko pasien jatuh. Disamping itu, kurang patuhnya perawat dalam melaksanakan standar resiko pasien jatuh karena kurangnya pengawasan oleh bagian keperawatan. Oleh sebab itu, adanya peningkatan program pelatihan atau sosialisasi khususnya mengenai pencegahan kejadian keselamatan pasien bagi tenaga keperawatan dan pelatihan mengenai mengasuh pasien yang beresiko 
jatuh sesuai standar rumah sakit untuk menjaga keamanan dan keselamatan pasien. Selain itu, perlu adanya pengawasan yang ketat sebagai langkah awal untuk mendisiplinkan perawat dalam kepatuhan perawat melaksanakan kewaspadaan resiko pasien jatuh dalam memberikan asuhan keperawatan pada setiap waktu dan kepada setiap pasien.

\section{PENUTUP}

\section{Kesimpulan}

Berdasarkan hasil dari pembahasan diatas dapat disimpulkan bahwa, selain peran perawat dalam memberikan asuhan keperawatan di ruang rawat inap, peran keluarga sangat dibutuhkan dalam menjaga pasien terlebih kepada pasien yang memiliki resiko tinggi terjadi kondisi yang tidak diinginkan seperti pasien jatuh dari tempat tidur. Oleh karena itu, dibutuhkan juga edukasi dari perawat kepada keluarga pasien tentang resiko pasien jatuh atau solusi-solusi untuk mencegah kejadian yang tidak diinginkan dengan memberikan pendidikan kesehatan, dan juga perhatikan respon keluarga pada saat diberikan pendidikan kesehatan, sehingga pihak keluarga dapat memahami pentingnya peran keluarga dalam pencegahan pasien jatuh di rumah sakit

\section{Saran}

Sebaiknya perawat lebih memberikan pendidikan kesehatan kepada keluarga pasien sehingga pihak keluarga tidak cemas membantu pasien melakukan aktivitas tertentu dengan bantuan keluarga karean perawat tidak 24 jam berada di dalam ruang rawat inap pasien. 
DAFTAR PUSTAKA

Dewi, M. (2012). Pengaruh Pelatihan Timbang Terima Pasien Terhadap Penerapan Keselamatan Pasien Oleh Perawat Pelaksana Di RSUD Raden Mattaher Jambi. Jurnal Health \& sport. Vol. 5(3). Hal 648650.

Firawati. (2012). Pelaksanaan Program Keselamatan pasien Di RSUD Solok. Jurnal Kesehatan Masyarakat. Vol. 6 (2). Hal 74-77.

Kamil, H. (2016). Patient Safety. Idea Nursing Journal . Vol. 1 (1). Hal 13.

Marina, 2017, Faktor-Faktor Yang Berhubungan Dengan Pencegahan Jatuh Pada Pasien Risiko Jatuh Oleh Perawat Di Ruang Nusa Indah RSUD Tugurejo Semarang, Diakses dari http://journal.undip.ac.id/index.ph $\underline{p}$.

Mustakim. 2015. Faktor-faktor yang mempengaruhi kejadian jatuh pada lansia di balai layanan social lanjut usia dewanata cilacap, Diakses dari http://journal.univmuhammadiyah. ac.id/ index.php.
Najihah. (2018). Budaya Keselamatan Pasien Dan Insiden Keselamatan Pasien Di Rumah Sakit: Literature Review. Journal of Islamic Nursing. Vol. 3 (1). Hal1-4.

Nursalam, 2015. Manajemen Keperawatan Aplikasi Dalam Praktek Keperawatan Professional Edisi IV. Jakarta : Salemba Medika

Peraturan Menteri Kesehatan Republik Indonesia Nomor 1691 Tahun 2011 Tentang Keselamatan Pasien.

Simamora, R. H. (2019). Buku ajar pelaksanaanidentifikasipasien. $U w$ aisInspirasi Indonesia.

Sugeng, B., Arif, A., \& Tri, W. 2014. Pelaksanaan Program Manajemen Pasien Dengan Risiko Jatuh Di Rumah Sakit. Jurnal Kedokteran Brawijaya. vol 28.

Utarini, A., Djasri, H. (2012). Keselamatan Pasien Dan Mutu Pelayanan Kesehatan. Jurnal Manajemen Pelayanan Kesehatan. Vol.15 (4). Hal 159-160. 